\title{
NILAI NASIONALISME DALAM KOMIK: KAJIAN SEMIOTIKA KOMIK RENGASDENGKLOK
}

\author{
Herliyana Rosalinda, Khikmah Susanti, Widya Nuriyanti
}

\author{
Program Studi Desain Komunikasi Visual \\ Fakultas Bahasa dan Seni, Universitas Indraprasta PGRI \\ herliyanarosalinda1990@gmail.com, soezhan99@gmail.com, widyanuriyanti@gmail.com
}

\begin{abstract}
Abstrak
Komik merupakan salah satu media bacaan yang diminati anak-anak dan juga orang dewasa. Di dalamnya berisi alur cerita dengan gambar yang ekspresif diperjelas dialog membuat komik dapat dibaca dan dipahami oleh semua kalangan. Isi komik biasanya menampilkan cerita ringan sehari-hari, penokohan heroik, ataupun cerita fiksi anak-anak. Artikel ini membahas tentang nilai nasionalisme yang tersirat dalam sebuah komik sejarah peristiwa Rengasdengklok dalam kajian semiotika. Komik tersebut merupakan komik yang dipakai sebagai media edukasi bagi anak dengan rentang usia 12 sampai 15 tahun yang diberi judul "Dibalik Bait Proklamasi". Tinjauan nilai nasionalisme dalam komik ini dilakukan untuk membuktikan adanya korelasi antara judul komik dengan isinya. Sehingga komik tersebut dapat menjadi media edukasi bagi anak-anak yang membawa pengaruh untuk menanamkan nilai nasionalisme. Hasil kajian semiotika dalam komik ini terlihat bahwa terdapat dua dialog dalam dua halaman berbeda. Terdapat ekspresi wajah dan gerakan tubuh serta kata-kata yang menunjukkan semangat perjuangan menuju kemerdekaan yang diucapkan oleh golongan pemuda.
\end{abstract}

Kata kunci : Nasonalisme, Semiotika, Komik, Rengasdengklok.

\begin{abstract}
Comics are one of the reading media that are of interest to children and adults alike. In it contains the storyline with expressive images that are clarified by dialogue making comics can be read and understood by all groups. Comic content usually displays light daily stories, heroic characterizations, or children's fiction. This article discusses the value of nationalism implied in a historical comic of the Rengasdengklok incident in the study of semiotics. The comic is a comic that is used as an educational medium for children aged 12 to 15 years, entitled "Behind the Proclamation Temple". An overview of the value of nationalism in this comic is done to prove the correlation between the title of the comic and its contents. So that the comic can be an educational medium for children which has an influence to instill the value of nationalism. The results of the study of semiotics in this comic show that there are two dialogs on two different pages. There are facial expressions and body movements as well as words that show the spirit of the struggle towards independence spoken by the youth group.
\end{abstract}

Keyword : Nationalism, Semiotic, Comic, Rengasdengklok.

\section{PENDAHULUAN}

Di dalam mukadimah Undang-Undang Dasar Republik Indonesia tahun 1945 akan terlihat bahwa para pendahulu kita yang telah memproklamasikan Republik ini dengan jelas-jelas mengemukakan arti "merdeka" bagi seluruh rakyat Indonesia, tanpa kecuali. Atas dasar itu, pendidikan Indonesia secara terbuka menjamin kebebasan hak rakyat Indonesia untuk mendapat pendidikan yang sebaik mungkin. Hal ini juga dapat dilihat 
dalam pasal 31 UUD 1945 bahwa pemerintah Indonesia mengusahakan dan menyelenggarakan satu sistem pendidikan nasional, yang meningkatkan keimanan dan ketakwaan serta akhlak mulia dalam rangka mencerdaskan kehidupan bangsa yang diatur dengan undang-undang.

Kenyataan yang dipaparkan diatas cukup bertolak belakang dengan keadaan sistem pendidikan Indonesia sekarang. Menurut Maarif (Kompas, 17 juni 2014) Sistem pendidikan nasional belum banyak beranjak dari nuansa kolonial sehingga tidak melahirkan manusia cerdas dan merdeka, bangsa Indonesia piawai dengan konsep tetapi lemah pada implementasinya. Dari beberapa berita media massa yang memuat berita mengenai dinamika pendidikan Indonesia akan banyak ditemui fakta dan opini negatif mengenai pendidikan, baik itu dari guru, kepala sekolah, instansi pendidikan sampai kepada sistem yang berlaku pada pendidikan (Asyhar, 2012: 14).

Melalui arahan yang tepat anak-anak dapat termotivasi dengan kesadaan mereka sendiri untuk mengesplorasi diri dengan pegetahuan yang baru. Hal tersebut bisa dilakukan salah satunya dengan memberi bacaan yang menarik, misalnya komik. Komik merupakan media visual berupa gambar dengan alur cerita yang berurutan berupa kolomkolom yang disertai teks atau dialog. Dengan adanya komik diharapkan mau membaca tanpa perasaan terpaksa atau harus dibujuk (Sudjana dan Rivai, 2005: 68).

Hal di atas tentunya tidak terlepas dari anggapan bahwa cerita komik lebih mudah dicerna dengan bantuan gambar yang ada di dalamnya.Kelebihan dari bacaan yang berbentuk komik ini telah banyak dimanfaatkan oleh negara-negara maju sebagai alat untuk meningkatkan minat belajar anak pada buku-buku pelajaran. Salah satu negara yang telah memanfaatkan komik sebagai salah satu pendukung keberhasilan pendidikannya adalah Jepang. Di negara ini, komik bukan merupakan benda asing yang digunakan sebagai media dalam pembelajaran. Bahkan, beberapa buku sekolah di Jepang diterbitkan dalam bentuk komik.

Kenyataannya, komik menjadi media yang efektif dan diminati siswa dengan gambar dan cara bertuturnya yang lugas. Komik dengan gambar, alur cerita yang ringkas tanpa mengurangi dari substansi isi cerita, dan bahkan disuguhi dengan setiap gerakan yang dilakukan oleh tokoh di dalam komik dengan catatan angka yang menarik dapat meningkatkan minat baca dan tujuan pemahaman isi bacaan pun mudah tercapai.

Melalui kajian semiotika, artikel ini membahas nilai nasionalisme pada isi komik yang menjadi objek penelitian kami, yaitu komik sejarah tentang peristiwa Rengasdengklok. Kajian semiotika merupakan kajian yang tepat untuk mengetahui makna simbolis dari gerakan atau ekspresi dalam isi komik. Sehingga pemaknaan nilai nasionalisme dalam komik Rengasdengklok dapat dikaji apakah telah ada dan sesuai, atau bahkan sebaliknya.

Artikel ini sejalan dengan artikel penelitian yang ditulis oleh Dewi Indah Susanti (2018) dalam Jurnal Desain yang diberi judul "Kajian Semiotika pada Papan Reklame Kampanye Pemilihan Calon Gubernur dan Wakil Gubernur Jawa Barat 2018-2023". Hasil penelitian tersebut menemukan makna semiotika yang ditentukan oleh tampilan gambar dan sistem tanda terdapat pemaknaan yang ditemukan pada semua papan iklan reklame kampanye politik di Jawa Barat. 


\section{HASIL DAN PEMBAHASAN}

\section{Tinjauan Pustaka}

Nilai Nasionalisme

Pengertian Penanaman Nilai

Penanaman yang sering disebut internalisasi diartikan sebagai penggabungan atau penyatuan sikap, standar tingkah laku, pendapat dan seterusnya di dalam kepribadian. Reber, sebagaimana dikutip oleh Mulyana dalam mengartikulasikan pendidikan nilai (2004: 21) mengartikan internalisasi atau penanaman sebagai penyatuan nilai dalam diri sesorang atau dalam bahasa psikologi merupakan penyesuaian keyakinan, nilai, sikap, praktek, dan aturan-aturan baku pada diri seseorang.

Penelitian ini mengisyaratkan nilai yang diperoleh harus dapat dipraktekkan dan berimplikasikan pada sikap. Penanaman atau internalisasi ini akan bersifat permanen dalam diri seseorang. Sedangkan Ihsan (dalam Rosalinda, 2013) memaknai penanaman atau internalisasi sebagai upaya yang dilakukan untuk memasukkan nilai-nilai kedalam jiwa sehingga menjadi miliknya. Jadi masalah internalisasi atau penanaman nilai tidak hanya berlaku kepada pendidikan agama saja, tetapi pada semua aspek pendidikan, pada pendidikan pra-sekolah, pendidikan sekolah, perguruan tinggi, dan lain-lain. Internalisasi adalah pendalaman penghayatan terhadap suatu ajaran, doktrin atau nilai sehingga merupakan keyakinan dan kesadaran akan kebenaran doktrin atau nilai yang diwujudkan dalam sikap dan perilaku (Kamus Ilmiah Populer dalam Rosalinda, 2016).

\section{Nasionalisme}

Pembahasan semangat kebangsaan tentang kesadaran perjuangan kaum nasionalisme merupakan aspek terakhir dalam kajian teori pada penelitian ini. Nasionalisme sebagai unsur afektif yang perlu ditanamkan pada diri siswa. Pada penelitian ini, semangat kebangsaan dihubungkan dengan tindakan menanamkan kesadaran siswa dalam berperilaku. Hal tersebut sesuai dengan pandangan Amin Abdullah (dalam Ainun Yaqin, 2005: xviii), bahwa penanaman kesadaran dalam masyarakat Indonesia akan sebuah keragaman (plurality), kemanusiaan (humanity), kesatuan (unity), dan kesamarataan (equality) sangat penting dilakukan. Hal tersebut sebagai landasan untuk dapat menjadi solusi dalam megembangkan atau memupuk konsep semangat nasionalisme dalam individu.

Berdasarkan pandangan tersebut, peneliti menekankan pembinaan dan penanaman kesadaran perjuangan kaum nasionalisme dari peristiwa rengasdengklok pada siswa sebagai penjiwaan semangat nasionalisme. Semangat nasionalisme sangat perlu ditanamkan dalam setiap masyarakat Indonesia. Tidak terkecuali pada pendidikan, menurut peneliti, berpandangan bahwa dunia pendidikan mempunyai peran vital dalam membentuk generasi muda bangsa Indonesia yang berjiwa semangat kebangsaan. Pandangan peneliti tersebut diperkuat dalam pendapat Mukhlis Paeni (dalam Rosalinda, 2013), yang berpandangan saat ini, di masa modern dunia pendidikan memegang peranan penting dalam menciptakan generasi muda yang mempunyai semangat nasionalisme.

Semangat nasionalisme diartikan sebagai bagian budaya yang mencakup perasaan, komitmen, dan kesetiaan pada bangsa dan negara, serta rasa memiliki bangsa dan negara itu. Semangat nasionalisme berakar dari timbulnya kesadaran kolektif tentang ikatan tradisi untuk selalu menjaga identitas bangsa dari pengaruh budaya luar. Oleh karena itu, pemahaman dasar seperti itulah merupakan modal utama untuk memahami konsep keberagaman budaya dalam dunia pendidikan, sebagai pondasi menciptakan siswa yang 
paham terhadap jati diri bangsanya. Untuk itu, unsur semangat nasionalisme sangat perlu diterapkan dalam setiap proses pembelajaran, sekaligus menjadi harapan terjadi peningkatan rasa nasionalisme pada siswa dengan adanya penelitian ini.

\section{Kajian Semiotika}

Semiotika adalah suatu ilmu atau metode analisis untuk mengkaji tanda. Tandatanda adalah perangkat yang kita pakai dalam upaya berusaha mencari jalan di dunia ini, di tengah-tengah manusia dan bersama-sama manusia. Semiotika atau dalam istilah Barthes, semiologi pada dasarnya hendak mempelajari bagian kemanusiaan (humanity) memaknai hal-hal (things). Memaknai (to sinify) dalam hal ini tidak dapat dicampuradukkan dengan mengkomunikasikan (to communicate). Memaknai berarti bahwa objek-objek tidak hanya membawa informasi, dalam hal mana objek-objek itu hendak berkomunikasi, tetapi juga mengkonstitusi sistem terstruktur dari tanda (Barthes, 1988; Kurniawan, 2001 dalam Sobur, 2013).

"Jika ada seseorang yang layak disebut sebagai pendiri linguistik modern ialah sarjana dan tokoh besar asal Swiss: Ferdinand de Saussure," (John Lyons dalam Sobur, 2013: 38). Ada lima pandangan dari Saussure yang dikemudian hari menjadi peletak dasar dari stukturalisme Levi-Strauss, yaitu paangan tentang (1) signified (penanda) dan signified (petanda): (2) form (bentuk) dan content (isi); (3) langue (bahasa) dan parole (tuturan, ujaran); (4) synchronic (singkronik) dan diachronic (diakronik); serta (5) syntagmatic (sintagmatik) associative (paradigmatik) (Sobur 2013 : 46).

Komik

Komik (dari kata asing comic) adalah cerita dalam bentuk deretan kotak gambar yang umumnya disertai dengan tulisan yang mengungkapkan dialog tokoh dan narasi pencerita. Disamping itu terdapat pula jenis komik tanpa kata. Sedangkan kartun yang biasa mengungkapkan satir masyarakat yang berbentuk karikatural dan hanya menampilkan satu kotak gambar, tidak termasuk jenis komik. komik tidak terbatas pada bentuk sebuah buku, tapi juga berbentuk cerita bersambung yang terdapat pada majalah, tabloid atau surat kabar tertentu. Komik sebagai bacaan mempunyai penggemar atau pembacanya tersendiri. Komik yang berbentuk buku terdiri atas beberapa bentuk, jenis dan ragam. Komik dengan berbagai bentuk ini sebenarnya memiliki struktur cerita yang mirip dengan sebuah novel.

Komik merupakan media bacaan yang memiliki keunikan tersendiri. Mengingat keterbatasan ruang dan waktu, maka pada komik kata-kata menjadi terbatas sifat dan bentuknya. Pada komik, peran dan funsi kata-kata telah digantikan oleh gambar. Pada komik, penulis lebih dominan bertutur dengan gambar daripada kata-kata. Terlebih lagi pada komik jenis laga dan humor. Pada komik jenis ini beberapa adegan diisi dan dihiasi hanya dengan gambar, tanda-tanda semiotik dan onomatope, tanpa kata atau kalimat sedikitpun. Adegan gambar yang terdapat dalam komik dapat memiliki sifat dan kaidahkaidah seperti novel dan film hanya berbeda dalam cara, media dan wujud pengungkapannya saja. Dengan gambar seorang pengarang daat menjelaskan secara lebih mendalam sesuai dengan yang hendak diungkapkannya (Setyawati, 2009 : 101).

Menurut McCloud (2008: 9), komik merupakan pilihan yang berkesinambungan terdiri dari pencitraan, alur cerita, dialog, serta komposisi gestur. Komik dapat memiliki arti gambar-gambar serta lambang lain yang terjukstaposisi (berdekatan, bersebelahan) dalam urutan tertentu, untuk menyampaikan informasi dan mencapai tanggapan estetis dari pembacanya. Komik sesungguhnya lebih dari cerita bergambar yang ringan dan 
menghibur. Komik bukan hanya bacaan untuk anak-anak. Komik adalah suatu bentuk media komunikasi visual yang mempunyai kekuatan untuk menyampaikan informasi secara populer dan mudah dimengerti.

Kelebihan komik yang lainnya adalah penyajiannya mengandung unsur visual dan cerita yang kuat. Ekspresi yang divisualisasikan membuat pembaca terlibat secara emosional sehingga membuat pembaca untuk terus membacanya hingga selesai. Hal inilah yang juga menginspirasi komik yang isinya materi-materi pelajaran. Kecenderungan yang ada, anak tidak begitu menyukai buku-buku teks. Apalagi yang tidak disertai gambar dan ilustrasi yang menarik. Padahal secara empiris siswa cenderung lebih menyukai buku yang bergambar, yang penuh warna dan divisualisasikan dalam bentuk realitas ataupun kartun. Komik pembelajaran diharapkan mampu meningkatkan minat anak untuk membaca sehingga pada akhirnya tujuan informasi pada isi komik dapat dimaknai anak (Daryanto, 2012: 126).

\section{METODE PENELITIAN}

Penelitian ini memfokuskan pada kajian semiotika berupa analisis tanda ekspresi pada komik sejarah Rengasdengklok yang mengambarkan sisi nilai nasionalisme yang tersirat pada berapa panel dibagian isi komik. Dalam sebuah penelitian memerlukan rancangan penelitian berupa tahapan dan metode apa yang dipakai. Rancangan penelitian adalah bagaimana data dikumpulkan dan dianalisis. Penelitian ini menggunakan metode kualitatif, dimana data primer didapat dari lapangan dan data sekunder melalui literatur untuk kemudian dianalisis secara deskriptif. Tahapan dalam Penelitian kualitatif ini: a) Pengumpulan data lapangan yakni data observasi sebagai data primer dan data literatur sebagai data sekunder, b) reduksi data yaitu penyederhanaan, penyusunan kembali, dan pengklasifikasian data, c) penyajian data berupa deskripsi dan memberikan arti sesuai dengan tujuan penelitian, dan d) penarikan kesimpulan. Tahapan analisis data sebenarnya dimulai saat reduksi data sampai dengan penarikan kesimpulan (Ratna, 2010:310-311).

Analisis semiotika pada komik dilakukan melalui beberapa tahapan, sebagai berikut: a) mendefinisikan objek analisis yaitu komik peristiwa Rengasdengklok berjudul "Di Balik Bait Proklamasi", b) mengupulan dokumen berupa isi komik, c) menjelaskan/ mengidentifikasi teks pada komik yang terdapat ikon/ simbol nasionalisme (misal: gerakan bersemangat, mengepalkan tangan, memandang lambing Negara, mencium bendera), d) mentafsirkan teks tersebut, e) menjelaskan kode-kode kultural, f) membuat kesimpulan dengan menghubungkan hipotesis (Sobur, 2013: 34).

Berdasarkan tahapan analisis semiotika tersebut, maka bagian-bagian yang dianalisis meliputi seluruh halaman isi pada komik yang berupa ekspresi wajah dan tubuh pada karakter komik dan teks dialog/ percakapan mereka.

\section{HASIL DAN PEMBAHASAN}

Hasil penelitian merupakan tahap awal dalam penelitian ini. Diantaranya terdapat penjabaran mengenai hasil dari studi pendahuluan, meliputi dua kegiatan, yaitu studi literatur. Studi literatur mengkaji teori dan hasil-hasil penelitian yang relevan dengan penelitian yang akan dilakukan. Kegiatan dalam studi literatur meliputi studi yang menamati isi terutama tentang ekspresi simbolis dari gambar pada komik Rengasdengklok menggunakan kajian semiotika. 


\section{Komik Peristiwa Rengasdengklok}

Komik peristiwa Rengasdengklok berjudul "Di Balik Bait Proklamasi" ini merupakan komik sejarah yang digunakan sebagai salah satu media pembelajaran bagi anak usia 12 sampai 15 tahun. Komik ini merupakan bahan uji coba penelitian pada tesis salah satu tim peneliti yaitu Herliyana Rosalinda dalam uji coba media menggunakan metode Research and Development. Komikusnya/ pembuat ilustrasi gambarnya merupakan animator berasal dari Yogyakarta yang bernama Ardyansyah Eka Permana, sedangkan penyusun naskah atau teks dialog komik dikerjakan oleh peneliti sendiri. Struktur dalam komik ini meliputi; a) penokohan dibagi menjadi dua ada golongan muda dab golongan tua. Golongan muda yang mendominasi yaitu pada tokoh bernama Sutan Syahrir, sedangkan golongan tua yang mendominasi yaitu Soekarno. b) alur cerita maju. c) Tema komik yaitu bertema sejarah dan pesan moralnya tentang semangat nasiobalisme, d) gambar dan bahasa, untuk gambar animasi komik bertipe animasi gaya barat seperti misalnya pada komik-komik keluaran Marvel dan DC.

\section{Naskah Komik}

Naskah komik ini diambil dari salah satu peristiwa sejarah sebelum kemerdekaan Indonesia, yaitu peristiwa penculikan Soekarno dan M. Hatta di daerah Rengasdengklok Jawa Barat. Naskah komik menunjukkan gambaran kasar dari komik yang akan dikembangkan berupa dialog pendek yang diucapkan pada tokoh dalam komik. Dimulai dari sampul komik, kemudian masuk menuju halaman pendahuluan yang berisi penjelasan situasi awal dan kalimat pengantar cerita. Setelah itu mulai masuk pada halaman komik peristiwa Rengasdengklok yang dimulai dengan percakapan dari golongan muda tentang kekalahan Jepang terhadap sekutu, kemudian pada halaman selanjutnya berlanjut cerita tersebut sampai pada akhir cerita menggambarkan situasi upacara proklamasi kemerdekaan Republik Indonesia pada tahun 1945. Pada halaman akhir dicantumkan keterangan gambar berupa pengenalan tokoh-tokoh. Setelah naskah selesai dibuat, selanjutnya dijadikan dialog antar tokoh dalam komik peristiwa Rengasdengklok. Dialog di kelompokkan sesuai dengan sketsa gambar pada tiap bagian percakapan.

\section{Tampilan Komik Rengasdengklok}

Komik ini terdapat 29 halaman, dan terdiri dari tiga bagian, yaitu halaman sampul, isi. Bagian isi berupa pengenlan tokoh karakter pada komik. Pada halaman sampul, komik ini diberi judul "Di Balik Bait Proklamasi" dengan ilustrasi gambar utama berada di tengah yaitu karakter tokoh Soekarno dan dikelilingi tokoh karakter lainnya seperti M. Hatta, Fatmawati, Sayuti Melik, dan lain-lain.

Halaman isi komik diberi efek shepia atau warna kuning kecoklatan sebagai warna dasar, dan pada sketsa diberi efek arsiran dan pewarnaan hitam yang mempertegas siluet dan bayangan pada gambar. naskah dan dialog rata-rata berada dipinggir gambar. Naskah berupa kalimat pengantar diletakkan pada satu halaman penuh yang berposisi di tengah kertas. Huruf yang digunakan adalah Comic San MS ukuran 14 dan latar halaman berwarna hitam sementara tulisan berwarna kuning. Kemudian dialog yang disisipkan pada gelembung kosong di sketsa komik sesuai dengan alur percakapan dan situasi pada sketsa tersebut. 


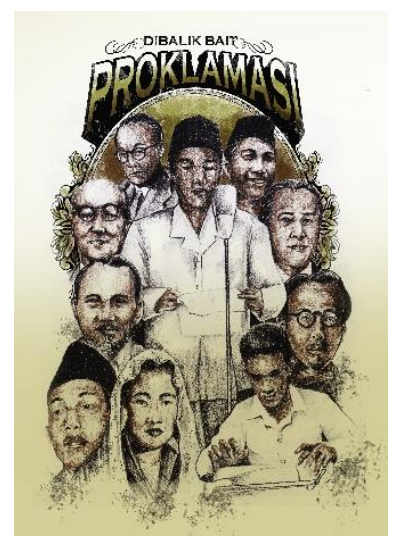

(1)

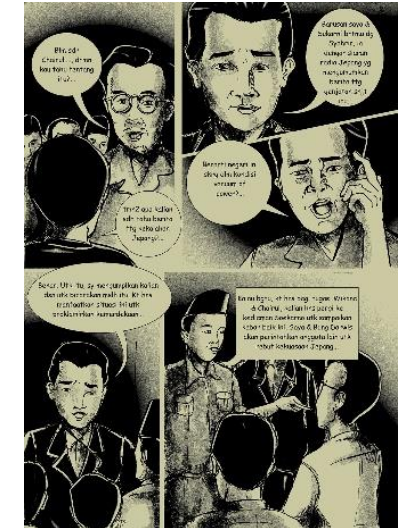

(2)

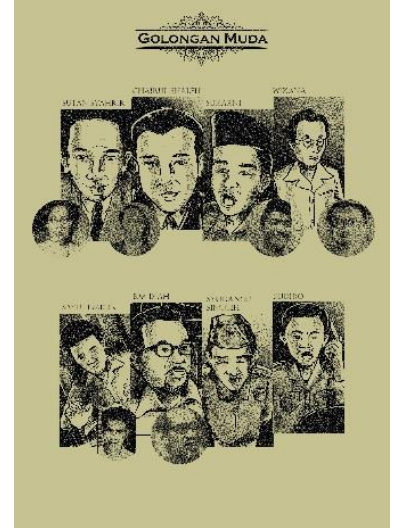

(3)

Gambar 1. Tampilan Komik; (1) Halaman Sampul, (2) Contoh Isi Komik, (3) Halaman Akhir PenjelasanTokoh

Sumber : Dokumentasi Pribadi

\section{Nilai Nasionalisme dalam Komik}

Setiap karya dibuat pasti meniliki tujuan dan kegunaan yang tersampaikan didalamnya. Baik itu mudah dipahami secara lugas ataupun membutuhkan pemahaman yang lebih untuk mencernanya. Sebuah pesan moral sebagai sarana pendidikan untuk anak biasanya harus disajikan dalam bentuk yang sesuai minat mereka. Sehingga tujuan penyampaiannya bisa dicerna. Misalnya pada sebuah buku cerita dan komik yang memiliki daya tarik bagi anak. Buku cerita atau komik tersebut menampilkan gambar menarik bagi motorik visualnya. Maka dengan begitu upaya penyampaian pesan moral lebih efektif apabila disampaikan pada kedua media tersebut.

Nilai nasionalisme sebagai salah satu pesan moral yang harus ada pada diri masyarakat. Ditengah perkembangan zaman, globalisasi dan bebasnya kebudayaan dari negara lain masuk ke negara kita, masyarakat memerlukan pondasi kuat untuk tetap mempertahankan kesatuan bangsa. Hal tersebut bisa dicegah apabila pada diri setiap masyarakat memiliki rasa nasionalisme. Pemahaman nasionalisme yang diterapkan pada lembaga pendidikan dari tingkat sekolah dasar hingga tingkat atas menjadi upaya yang baik untuk menumbuhkan kesadaran nasionalisme sejak dini.

Komik sejarah tentang cerita peristiwa Rengasdengklok yang menjadi objek pada artikel ini merupakan salah satu media yang berhasil dalam penyampaian pesanmoralnya pada kalangan anak usia 12 hingga 17 tahun. Hal itu telah terbukti pada penelitian sebelumnya yang sudah dilakukan oleh tim kami, yaitu uji coba media pembelajaran melalui komik ini pada sekolah SMP dan SMA. Salah satu faktor keberhasilan dari komik ini didasari karena dalam penyampaian pesannya dapat dipahami oleh anak. Pesan moral yang dapat diambil yakni tentang nilai nasionalisme yang tersirat pada beberapa panel komik. Nilai nasionalime ini dapat diketahui melalui kajian semiotika yang melihat ketersinambungan antara tanda berupa gambar ekspresi dan dialog pada komik.

Pada isi komik ini ada beberapa panel atau halaman yang dengan jelas memperlihatkan tanda bahwa karakter di dalamnya menampilkan nilai nasionalisme. Pertama pada halaman kedua, yaitu dengan situasi golongan muda yang terdiri dari Chairul Saleh, Sutan Syahrir dan Sukarni sedang berbincang tentang kabar Jepang yang sudah kalah dengan Sekutu. Maka timbulah rasa nasionalime mereka dengan ingin segera memerdekakan negara kita dengan upaya kita sendiri bukan dengan bantuan negara lain. Hal itu tersampaikan pada kutipan dialog; diawali oleh Chairul Saleh dengan ekspresi 
antusias yang diperlihatkan dari wajah yang serius dan tangannya terbuka lebar mengatakan "Kalau begitu kita harus segera memproklamirkan kemerdekaan. Rakyat sudah tidak sabar untuk segera lepas dari belenggu penjajahan", kemudian perkataan Chairul Saleh disambut Sukarni dengan ekspesi yang lebih antusias menyuarakan rasa nasionalismenya dengan mengepalkan tangan ia berkata "Benar sekali. Jepang sudah tidak punya wewenang lagi di negeri ini. Kita harus memanfaatkan momen ini!". Kutipan percakapan tersebut terlihat pada gambar berikut ini:

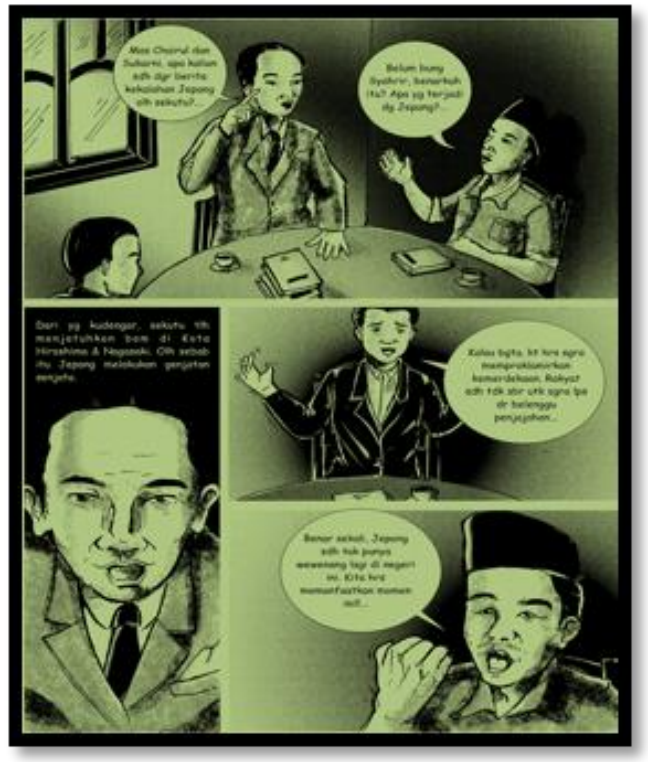

Gambar 2. Percakapan golongan muda pada komik di halaman 2 Sumber: Dokumentasi Pribadi

Kedua, nilai nasionalisme terlihat pada komik di halaman 15 yang memperlihatkan percakapan antara golongan muda (Syodanco Singgih) dan golongan tua (Soekarno, M. Hatta dan Ahmad Soebardjo) yang telah sepakat memproklamasikan kemerdekaan. Rasa nasionalisme Syodanco Singgih diutarakan dengan mencoba meyakinkan golongan tua yang awalnya masih menunggu keputusan Jepang untuk memerdekakan Indonesia. Syodanco Singgihberkata “... saya yakin kita dapat bangkit dan memanfaatkan situasi ini, kesempatan (merdeka) tidak datang dua kali..."pernyataan sepakat dari Soekarno yang terlihat menunjukan nasionalismenya terlihat saat ia berkata "... baiklah kita akan memerdekakan (Indonesia) tanpa campur tangan Jepang. 


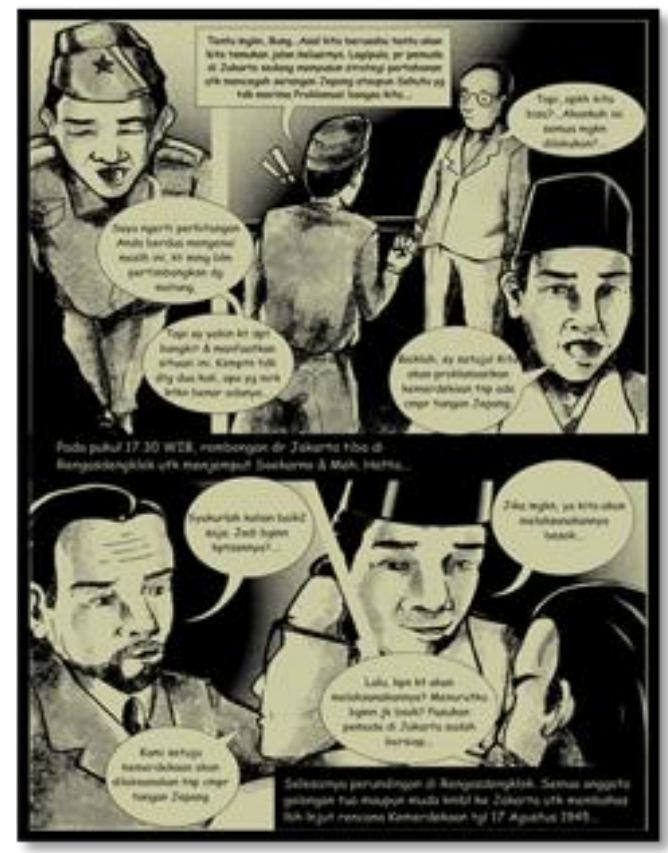

Gambar 3. Kesepakatan untuk merdeka pada komik halamn 15 Sumber: Dokumentasi Pribadi

Komik ini menggambarkan dua karakteristik yang berbeda antara golongan muda dan golongan tua. Golongan muda merupakan pemuda Indonesia dengan usia remaja digambarkan sebagai usia yang sedang produktif, enerjik dan penuh semangat. Golongan tua digambarkan dengan sifat yag matang penuh pertimbangan dan rencana kedepan. Di akhir komik ini dijelaskan dengan adanya rundingan di Rengasdengklok maka dibentuklah upaya persiapan kemerdekaan yang jatuh pada tanggal 17 Agustus 1945.

Peristiwa Rengasdengklok memberi bukti bahwa antara orang tua dan pemuda harus bekerjasama untuk mendapatkan keputusan yang adil. Maka sesuai dengan kata mutiara dari Soekarno yang berbunyi "Beri aku 1000 orang tua niscaya akan ku cabut Semeru dari akarnya, berikan aku 1 pemuda, niscaya akan kuguncangkan dunia". Sosok pemuda yang digambarkan oleh Soekarno yaitu pemuda yang dapat memberikan perubahan bukan hanya untuk bangsa tapi juga dunia. Komik ini dengan segmentasi pembacanya anak-anak usia remaja dirasa sesuai agar makna atau pesan moral dalam komik tersebut dapat tercapai.

Dari dua panel tersebut, terlihat adanya upaya golongan muda yang bersemangat untuk segera memerdekakan Indonesia tanpa bantuan Jepang ataupun pihak lain. Hal ini membuktikan bahwa mereka memiliki rasa nasionalisme yang tinggi. Anak-anak sebagai membaca komik ini, menjadi paham akan pentingnya rasa nasionalisme dalam diri yang dicontohkan.

\section{SIMPULAN}

Terdapat tanda dalam percakapan yang menunjukkan rasa nasionalisme dalam komik Rengasdengklok, yaitu terlihat pada panel komik halaman dua dan 15. Dua panel tersebut berisi tentang bagaimana golongan pemuda sangat bersemangat untuk memerdekakan Indonesia, dan komik ini dapat dijadikan rekomendasi bahan bacaan untuk anak-anak agar memupuk nilai nasionalisme bangsa sejak dini. 


\section{DAFTAR PUSTAKA}

Asyar, R. (2012). Kreatif Mengembangkan Media Pembelajaran. Jakarta: Referensi Jakarta.

Daryanto. (2012). Media Pembelajaran. Bandung: PT Sarana Tutorial Nuarani Sejahtara.

Indah Susanti, Dewi. (2018). Kajian Semiotika pada Papan Reklame Kampanye Pemilihan Calon Gubernur dan Wakil Gubernur Jawa Barat 2018-2023. Jurnal Desain, 6 (1), 27-33.

Kompas, Edisi Senin, 17 Juni 2014

McCloud, S. (2008). Understanding Comic. Jakarta: PT Gramedia Pustaka Utama.

Ratna, N.K. (2010). Metode Penelitian: Kajian Budaya dan Ilmu Sosial Humaniora pada Umumnya. Yogyakarta: Pustaka Pelajar.

Rosalinda, H. (2013). Pengembangan Komik Rengasdengklok sebagai Media Pembelajaran pada Siswa di SMA Negeri 3 Surakarta. Tesis. Universitas Sebelas Maret Surakarta.

Setyawati, E. dkk. (2009). Sejarah Kebudayaan Indonesia, Seni Rupa dan Desain. Jakarta: Rajawali Press.

Sobur, A. (2013). Semiotika Komukasi. Bandung: PT. Remaja Rosdakarya Offset.

Sudjana, N. dan Rivai, A. (2010). Media Pengajaran. Bandung: Sinar Baru Algensindo.

Yaqin, A. (2005). Pendidikan Multi Kultural: Cross-Cultural Understanding untuk Demokarasi dan Keadilan. Yogyakarta: Nuansa Aksara. 